\title{
Application of Recapitulation and Staff Performance Assessment Using Standard Working Method
}

\author{
Agustia Hananto ${ }^{1}$ \\ Study Program \\ Information System \\ Faculty Of Engineering And Computer \\ Science, Universitas Buana Perjuangan \\ Karawang \\ agustia.hananto@ubpkarawang.ac.id
}

\author{
Eko Pramono ${ }^{2}$ \\ Study Program \\ Computer science \\ Faculty of Engineering and Informatics \\ Bina Sarana Informatika University \\ Indonesia \\ eko.eop@bsi.ac.id
}

\author{
Baenil Huda ${ }^{3}$ \\ Study Program \\ Information System \\ Faculty Of Engineering And Computer \\ Science, Universitas Buana Perjuangan \\ Karawang \\ baeni188@ubpkarawang.ac.id
}

\begin{abstract}
Abstrak-Evaluasi atau penilaian kinerja karyawan diperlukan untuk menilai pencapaian kerja atau prestasi kerja dari karyawan perusahaan terhadap target yang diberikan dalam waktu tertentu. Tujuan penelitian adalah untuk menganalisis metode rekapitulasi dan penilaian kinerja staf serta untuk membuat model rancang bangun aplikasi rekapitulasi dan penilaian kinerja staf. Metode penelitian yang digunakan adalah penelitian kualitatif dimana pengumpulan data dilakukan dengan cara observasi dan wawancara. Pengembangan aplikasi berdasarkan metode iterative waterfall digunakan untuk mengakomodir proses rekapitulasi dan penilaian kinerja karyawan tersebut. Manfaat dari penelitian yang dilakukan selain untuk mengetahui dampak dari keterlambatan informasi, juga untuk mempercepat proses rekapitulasi dan penilaian kinerja itu sendiri. Informasi mengenai pencapaian kerja setiap bulannya disajikan dalam aplikasi yang dapat dilihat oleh masing-masing karyawan. Hasil akhir rekapitulasi dan penilaian berupa nilai total dan rasio pencapaian prestasi kerja diharapkan mampu mempermudah kepala bagian dalam mengambil keputusan.
\end{abstract}

Kata kunci: Sistem informasi, karyawan, rekapitulasi, peniliaian kinerja

\begin{abstract}
Employee performance evaluation or appraisal is needed to assess company employees' work achievement or work performance against the given target within a specific time. The purpose of the study was to analyze the method of recapitulation and staff performance appraisal and create a design model for the application of recapitulation and staff performance appraisal. The research method used is qualitative research, where data collection is done using observation and interviews. Application development based on the iterative waterfall method accommodates the recapitulation process and employee performance appraisal. The benefits of the research carried out are to determine the impact of information delays and speed up the recapitulation process and the performance appraisal itself. Every month, information regarding work achievements is presented in an application that each employee can see. The final results of the recapitulation and assessment in the form of total values and ratios of work achievement are expected to facilitate the head of the department in making decisions.
\end{abstract}

Keywords: Information systems, employees, recapitulation, performance appraisal

\section{INTRODUCTION}

Evaluation and assessment is a thing that is commonly found in an organization, both academic, social and corporate organizations. Performance evaluation or assessment to individuals, work units, or work sub-units is closely related to awarding awards set by the institution or organization. Performance or performance can be defined as an individual or teamwork following predetermined work instructions. Evaluation or assessment of work performance is a routine program carried out by an organization, both government and private agencies, to determine steps in fostering or developing employees or employees following the results obtained from the evaluation or assessment. Evaluation or assessment of work performance is a routine program carried out by an organization, both government and private agencies, to determine steps in fostering or developing employees or employees following the results obtained from the evaluation or assessment [1].

Based on the interview results, following the company's internal policy that the recapitulation of work results is one of the elements in the performance appraisal. The assessment results will be submitted to each staff after the semester assessment period ends. In this case, the staff cannot improve because the final score results are final, and the team can only enhance work achievement in the following semester. This happens because there is no information to staff regarding work achievements every month in the current semester period.

Submission of information on work achievement every month to staff can have an indirect effect on the performance of the team themselves [2]. The results of interviews that have been conducted show that information about work achievements in the previous month is essential for the staff themselves. As a result, if the work achieved during the last month does not reach the target or is not good, the team can improve the following month. An integrated information system or application is expected to accommodate these needs by providing output in monthly work achievement data. Implementing the correct application can simplify and speed up evaluating employee performance [3]. So that feedback can be informed quickly to make the necessary 
improvements. So it is hoped that the built application can help optimize the performance of company employees [4] . and facilitate the supervision process [5].

\section{Definition of Performance Evaluation}

performance appraisal is a formal management system provided for evaluating the quality of individual performance in an organization [1]

\section{Staff Definition}

Staff are people who help a leader or chairman in managing something or a certain work unit [1]. For example, office staff, administrative staff, management staff, and so on

\section{Definition of Standard Working Method}

According to Mondy (2008), the working standards method is a method of evaluating performance by comparing work achievements with predetermined targets or expected outputs. Standards reflect the normal output of an average employee working at a normal pace. This assessment method can be applied in almost all types of work, but is generally used in production lines[6].

\section{Define flow map}

Flow map according to Wahyudi (2012)[7], "a diagram that shows the flow of data in the form of forms or information in the form of documentation that flows or circulates in a system. This diagram serves to determine the relationship between entities in a system.

\section{Definition of Unified Modeling Language}

According to Sri Mulyani (2016), Unified Modeling Language (UML) is a standard tool for a system development technique that uses a graphical language as a tool for documenting and performing system specifications [8].

\section{Definition of PHP and Codeigniter}

PHP stands for recursive PHP: Hypertext Preprocessor. PHP is a programming language that is specifically used for web application development [9]. Codeigniter is an open-source PHP framework or framework that can help speed up developers in creating or developing a web-based application [10].

\section{METHOD}

\section{A. Data Collection Techniques}

The research was conducted using qualitative methods, and data collection techniques were carried out by field observations, interviews, and literature studies [11]

1. Observation

2. The observation step was carried out by making direct observations of the operational contact center of PT. XYZ to get information or information that is directly related to the problem.

3. Interview

Interviews were conducted by giving several open and closed questions to the parties involved in the operational activities of the organization, namely department heads, team leaders, and staff.

4. Literature study

Books, literature, or library materials are used in research by taking notes and or citing expert opinions as supporting the theoretical basis of research.

\section{B. System Development Method}

The system development method used in this research is iterative waterfall. Iterative waterfall has advantages compared to the classic waterfall, namely it has feedback at each stage to the previous stage [12]. The choice of this method is not only because it is easy but also has advantages, namely when the system requirements are fully and explicitly defined, the system development will run well [13]. The steps or stages of system development with the iterative waterfall method are as follows [12]:

1. Analyze

Analyze is the stage where all things related to system development are analyzed. So that problems and needs are identified as well as solutions that can be applied.

2. Design

The results of the analysis carried out, the researchers then made an overview of the current process flow and the needs needed to make a design. The design made includes the application design using the Unified Modeling Language (UML) as the model.

3. Coding

The coding stage is the stage of pouring the results of the design into codes in programming languages [12]. The programming language used is PHP. The coding process follows the general rules and rules used in the Code igniter framework[10].

4. Testing

The process of testing the application from the coding results is done by means of black box testing. Where the functions of the application such as links, buttons, forms, and other elements can work or not [14].

5. Implementation

The implementation stage is carried out by researchers by installing and configuring applications on the server computer. In addition, socialization is also carried out to all users or users who have access to the application.

6. Maintenance

Maintenance actions are in the form of correcting errors found during testing and when the application is running. In addition, maintenance is also carried out on the application and database, namely cleaning the cache on the server computer and periodically backing up the database.

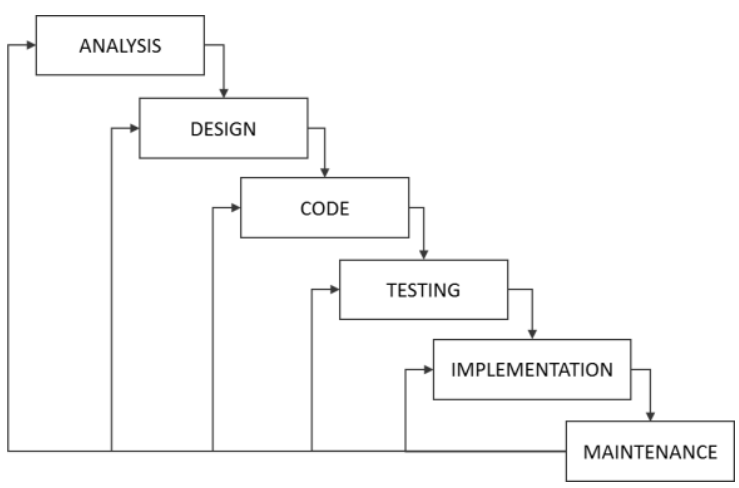

Figure 1 Iterative waterfall[12]

\section{RESULTS AND DISCUSSION}

\section{A. Current System Analysis}

The research was conducted at the Contact Center of PT. XYZ. Contact Center PT. XYX has a role in providing aftersales service to consumers, as an information service center 
for consumers via telephone, short message or Short Message Service (SMS), Whatsapp, electronic mail, and social networking media. From the results of observations and interviews, it was found that the performance appraisal of staff working at the Contact Center of PT. XYZ consists of four elements, namely work productivity, consumer satisfaction index or CS index, attendance, and product knowledge. The assessment process is carried out every six months or every semester. The staff team leader will recapitulate all elements of the assessment and perform calculations according to the calculation reference that has been determined. The results of the recapitulation and calculations will be submitted to the head of the department. After the assessment data is sent to top management, the department head will inform each staff of the performance value. The performance value is the final value, so if there is an element of an unfavorable assessment, it cannot be improved. Staff can make improvements in the next assessment period.

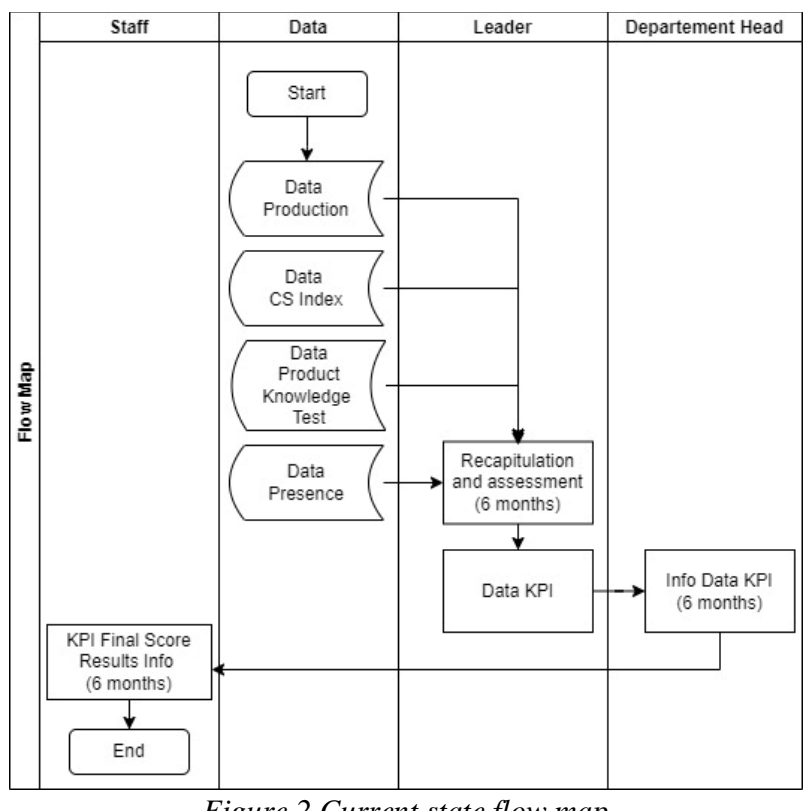

Figure 2 Current state flow map

Calculation method by determining the achievement of each element included in the range of certain classes in accordance with the targets and calculation provisions that have been determined. The result of the calculation with the target is expressed as a percentage. Furthermore, the percentage of the comparison results will be multiplied by the weight that has been set as well. The accumulated results of the weighting of all elements in the form of a percentage number are expressed as the final value or Key Performance Indicator (KPI). The formula for calculating the final value is stated as follows:

Final score $\sum$ (Work achievement classification $x$ Weight $)$

\section{Description}

Final Score

Work

achievement

classification
Weight

: Determined by internal

department, expressed in \%

Table 1 Classification of work achievements

\begin{tabular}{cc} 
Job achievement & Classification/criteria (\%) \\
$\mathrm{X}_{1} \sim \mathrm{X}_{2}$ & $\mathrm{xx} \%$ \\
$\mathrm{X}_{2} \sim \mathrm{X}_{3}$ & $\mathrm{xx} \%$ \\
$\mathrm{X}_{3}-\mathrm{X}_{4}$ & $\mathrm{xx} \%$ \\
$\cdots$ & $\cdots$ \\
$\mathrm{X}_{\mathrm{n}-1} \sim \mathrm{X}_{\mathrm{n}}$ & $\mathrm{xx} \%$ \\
\hline
\end{tabular}

\section{B. System Design}

\section{System Proposal}

Referring to the current conditions in the recapitulation process and performance appraisal of the Contact Center staff of PT. XYZ, the researcher proposes to build a web-based application to facilitate the process of recapitulation and staff performance appraisal, so that staff can see their respective work achievements every month and also as a monitoring support tool for department heads. The flow map of the application submitted is as follows:

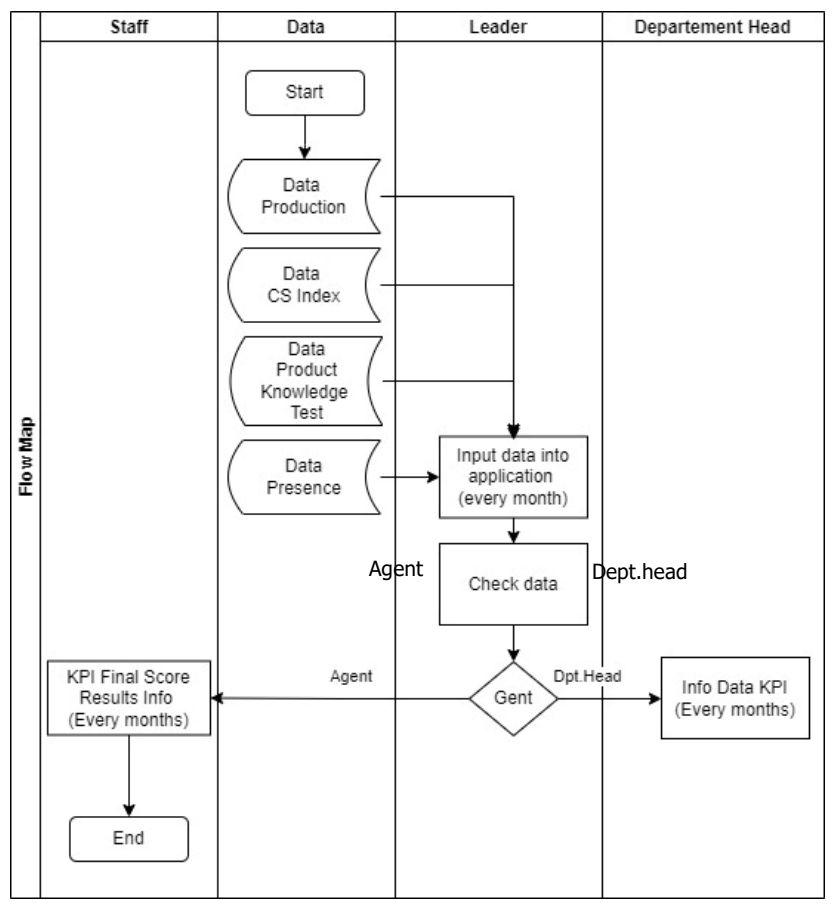

Figure 3 The proposed system flow map

In the flow map of the proposed system, staff or agents can see the achievement of work every month. So that if there are work achievements in the previous month that are not good, improvements can be made during the same assessment period.

\section{System Requirements}

The requirements in the system are outlined in the following table:

Table 2 System Requirements

\begin{tabular}{ccc}
\hline $\begin{array}{c}\text { Function } \\
\text { or }\end{array}$ & Requirement & Accees \\
position & & \\
\hline
\end{tabular}




\begin{tabular}{lll}
\hline $\begin{array}{l}\text { Team } \\
\text { leader }\end{array}$ & $\begin{array}{l}\text { Manage productivity data, CS } \\
\text { index, attendance, and product } \\
\text { knowledge test scores. }\end{array}$ & Admin \\
& $\begin{array}{l}\text { Save the assessment standards } \\
\text { that have been set. }\end{array}$ & \\
Staf & $\begin{array}{l}\text { View productivity data, CS } \\
\text { index, attendance, and product } \\
\text { knowledge test scores and their } \\
\text { respective final scores }\end{array}$ & Agent \\
Head of & $\begin{array}{l}\text { View productivity data, CS } \\
\text { index, absenteeism, and product } \\
\text { knowledge test scores, and the } \\
\text { final score of all staff. }\end{array}$ & $\begin{array}{l}\text { Department } \\
\text { head }\end{array}$ \\
& $\begin{array}{l}\text { Save the assessment standards } \\
\text { that have been set. }\end{array}$ & \\
\hline
\end{tabular}

By using the Unified Modeling Language (UML), the access requirements in the system are described in the following use case diagram::

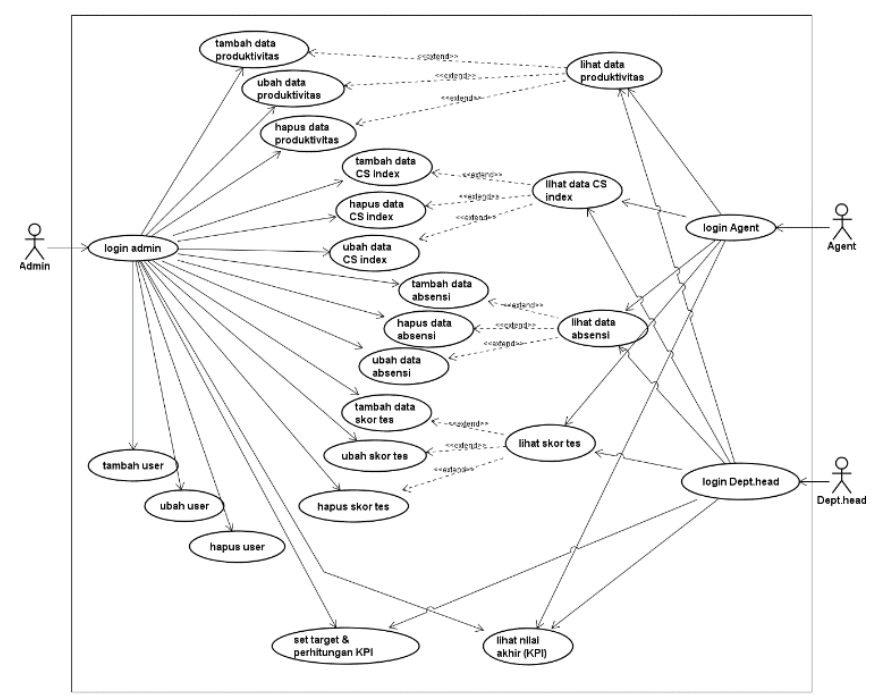

Figure 4 Use case diagram of the proposed system

\section{Activity Diagram}

Activity diagrams represent various activities or pieces of processes and sequences in the system [12].

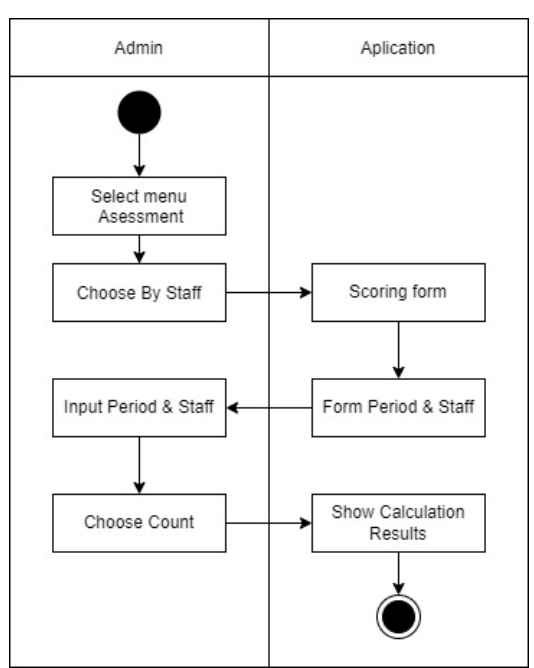

Figure 5 Activity diagram calculate the final score (KPI)

\section{Sequence Diagram}

Sequence diagrams are used to model the interactions between objects and also represent sample snippets of software system processes [15].

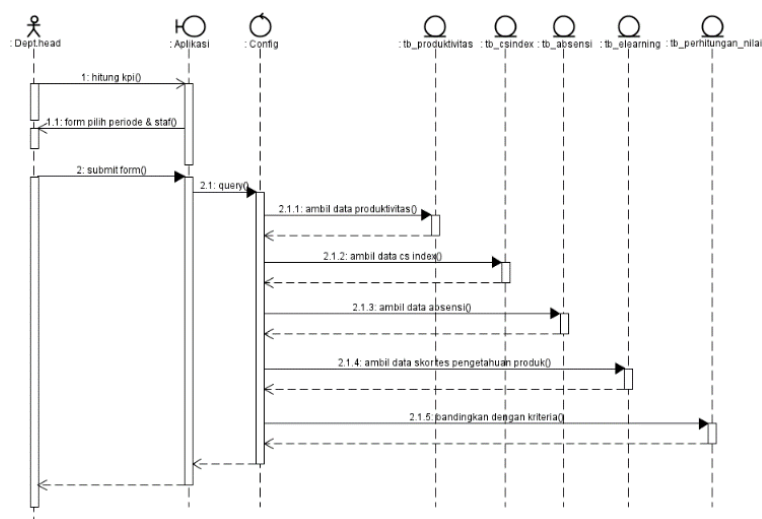

Figure 6 Sequence diagram calculate the final value

\section{Class Diagram}

Class diagrams describe the static structure of a system or how the system is structured. The static structure of a system consists of a number of classes and their dependencies. A class represents an entity that has attributes and functions[12].

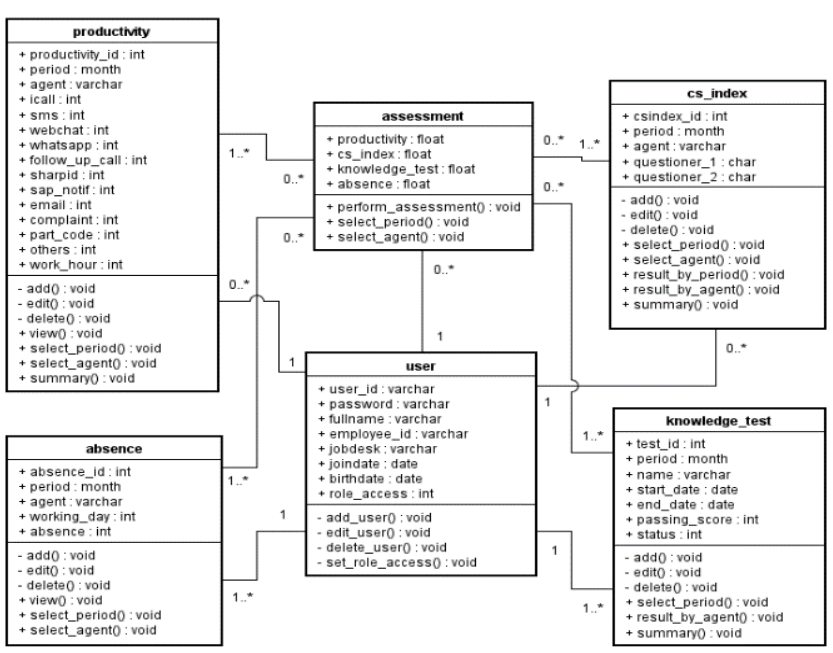

Figure 7 The proposed system class diagram

\section{Database Design}

Database or database is needed to store data that will be, is being, or has been processed in the application. The relationship between tables in a database consisting of several entities is as follows. 

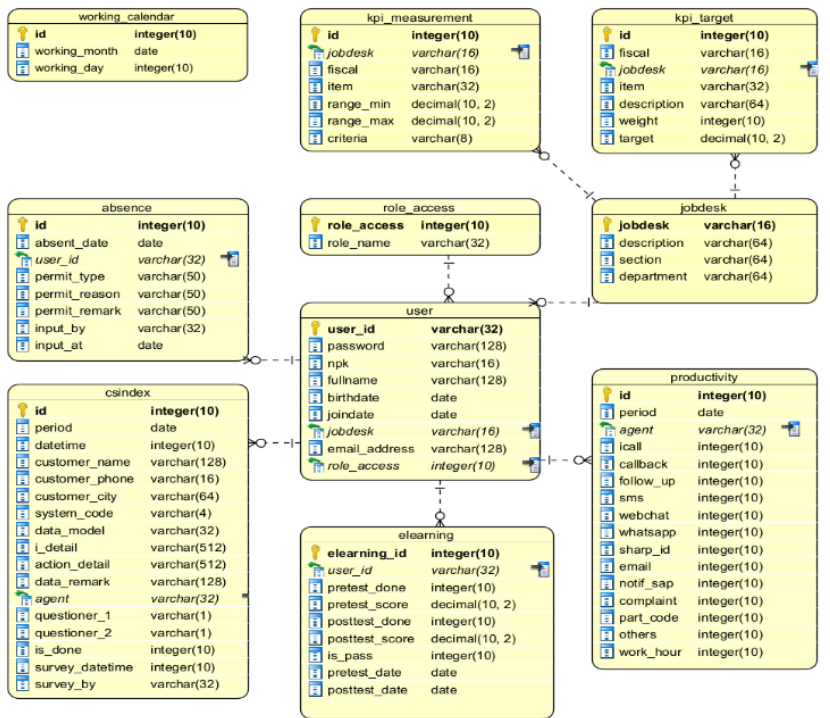

Figure 8 Relationships between tables in the database

\section{Interface Design}

Layout design describes the interface page (interface) designed on the application.

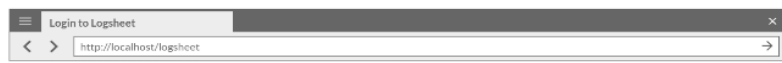

Figure 9 Application login page display design

After successful login, on the main page or dashboard, will display the user profile. The menu list is on the left.

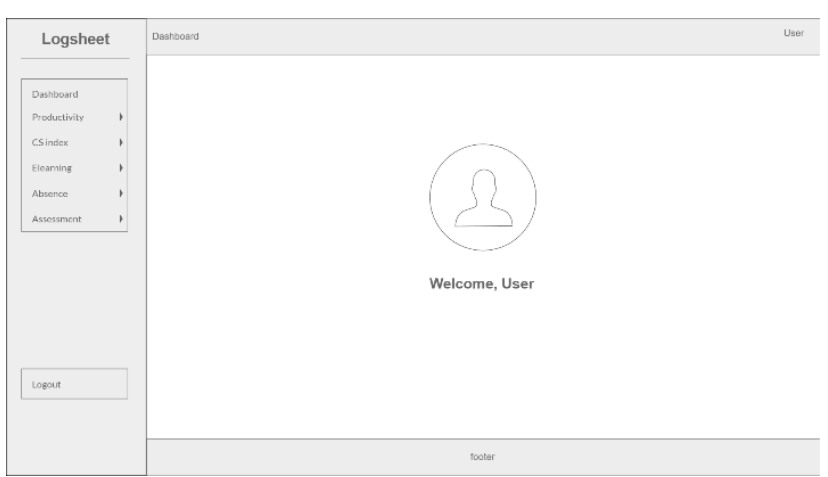

Figure 10 Dashboard page display designs

The following is the final value calculation page display design.

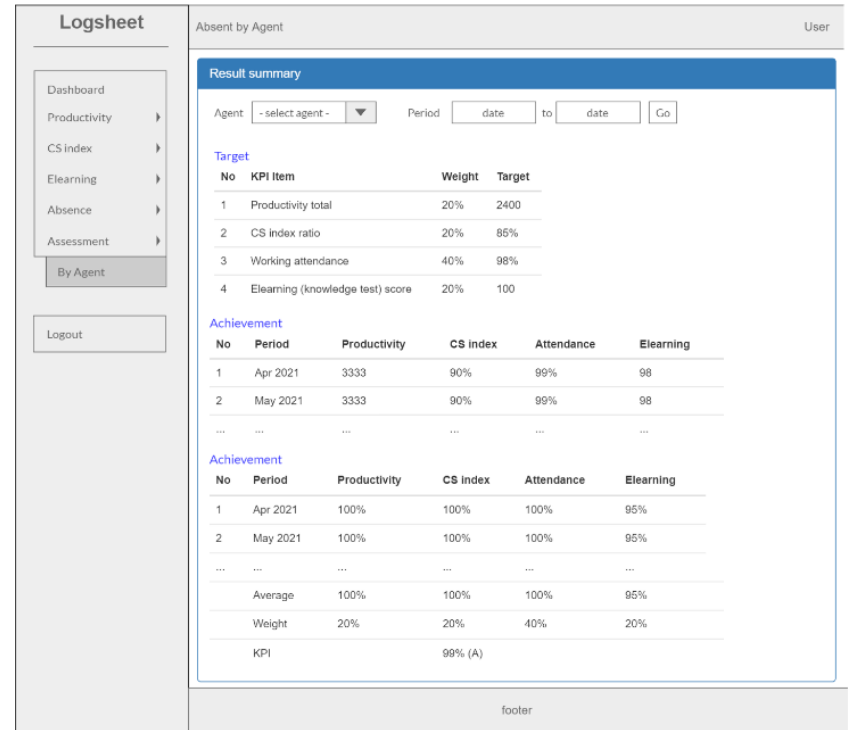

Figure 11 Staff KPI calculation page display design

\section{System Implementation}

The coding process or coding to translate the design that has been made into a program using the CodeIgniter PHP framework which is paired with the AdminLTE3 site. The application built is called Logsheet.

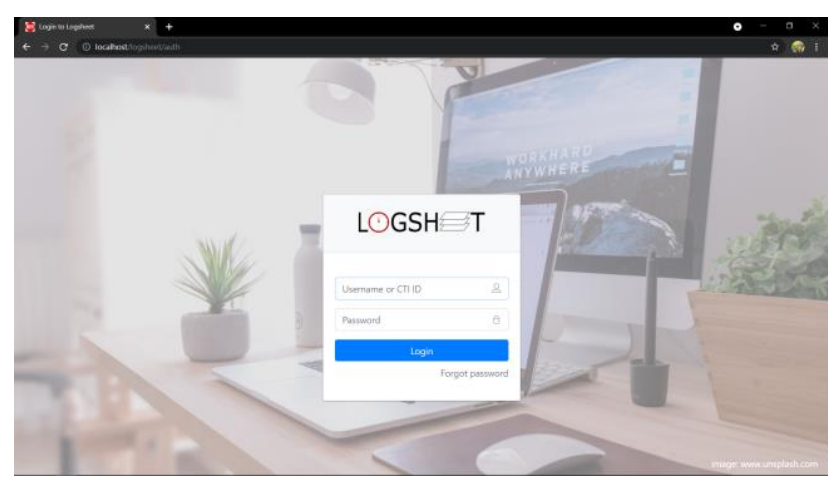

Figure 12 Login page display

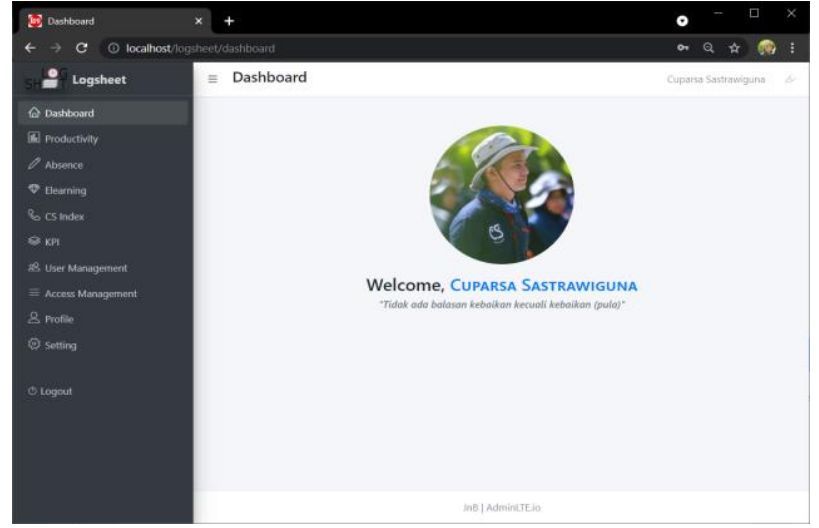

Figure 13 Dashboard page view 


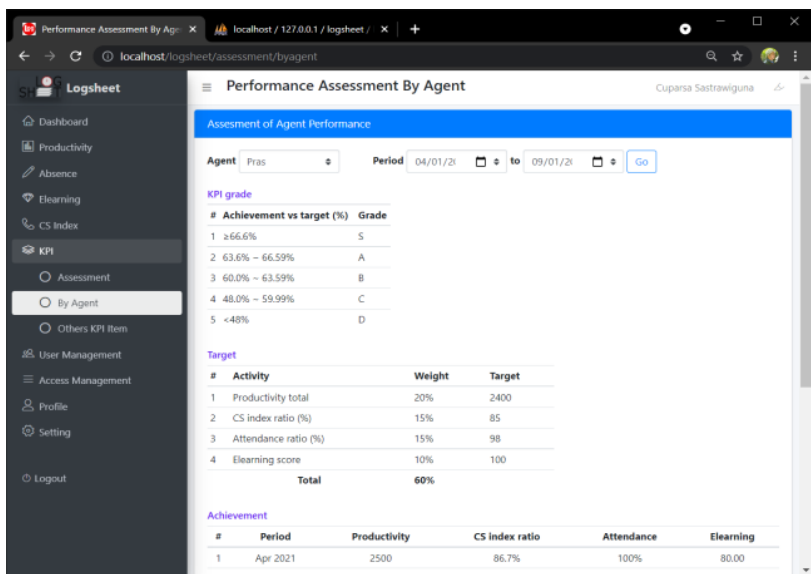

Figure 14 KPI calculation page view by staff

A. System Test

System testing with blackbox testing is carried out to ensure that the functions in the applications built do not contain errors or bugs when the application is run.

Table 3 Testing the final value calculation menu (KPI)

\begin{tabular}{lll}
\hline \multicolumn{1}{c}{ Process design } & \multicolumn{1}{c}{ Description } & Result \\
\hline $\begin{array}{l}\text { Select the "KPI by } \\
\text { agent" menu }\end{array}$ & $\begin{array}{l}\text { Display the final score } \\
\text { calculation page or KPI by } \\
\text { staff name }\end{array}$ & matching \\
$\begin{array}{l}\text { In KPI by agent, } \\
\text { choose the name of } \\
\text { the staff, the period } \\
\text { of the first month and } \\
\text { the end of the month }\end{array}$ & $\begin{array}{l}\text { Displays a selection of } \\
\text { staff name, starting month } \\
\text { and ending month. }\end{array}$ & $\begin{array}{l}\text { Login agent, unable to } \\
\text { select staff name }\end{array}$ \\
$\begin{array}{l}\text { In KPI by agent, } \\
\text { choose submit "Go" }\end{array}$ & $\begin{array}{l}\text { Displays a summary of } \\
\text { work achievements and } \\
\text { after selecting staff } \\
\text { name, starting and } \\
\text { ending month period } \\
\text { on the selected staff and } \\
\text { month }\end{array}$ & \\
$\begin{array}{l}\text { Select the "KPI } \\
\text { assessment" menu }\end{array}$ & $\begin{array}{l}\text { Displays the KPI } \\
\text { assessment page which } \\
\text { contains a summary of the }\end{array}$ & \\
& $\begin{array}{l}\text { KPI achievements of all } \\
\text { staff }\end{array}$ & \\
\hline
\end{tabular}

\section{CONCLUSION}

Some conclusions from the research this:

1. The developed web-based application can simplify evaluating staff performance at the Contact Center of PT. $\mathrm{XYZ}$. The calculation method in the application follows the provisions or standards that exist in the internal organization, both the targets to be achieved and the assessment reference.

2. The application developed can help staff monitor work achievement every month. So that if there are poor work achievements in the previous month, staff can find out more quickly and make performance improvements in the following month. In addition, the application can also be helpful for department heads if a special evaluation is needed for staff based on final grades.

\section{REFERENCE}

[1] M. Abdullah, Manajemen dan Evaluasi Kinerja Karyawan. Sleman: Aswaja Pressindo, 2014.

[2] D. A. Wardani, "Pengaruh Penerapan Aplikasi Sistem Informasi Akuntansi Terhadap Kinerja Karyawan Pada PD. BPR Rokan Hulu Pasir Penga iran," J. Chem. Inf. Model., vol. 53, no. 9, pp. 1689-1699, 2017.

[3] Y. Suherman and D. Yadewani, "Aplikasi Sistem Informasi Penilaian Kinerja Karyawan," J-Click, vol. 6, no. 2, pp. 201207, 2019.

[4] I. M. Hadi, T. Tukino, and A. Fauzi, "Sistem Informasi Monitoring Evaluasi Standar Pembelajaran Menggunakan Framework Codeigniter," Ciastech 2020, no. Ciastech, pp. 443-452, 2020.

[5] V. Felita, K. Saputra, S. Keputusan, K. Pendidikan, and B. Lampung, "Aplikasi Monitoring Kerja Karyawan ( E-Kinerja ) Berbasis Web Menggunakan Framework Codeigniter Di Citra Angkasa Tercipta ( Cat ) Bandar Lampung," J. Vania, pp. $1-8,2020$

[6] A. Marbawi, Manajemen Sumber Daya Manusia. Lhokseumawe: UNIMAL Press, 2016.

[7] Z. Makmur, "Pengembangan Sistem Informasi Permintaan Pembelian Kebutuhan Kantor pada Dealer Management System,” J. Teknosain, vol. XV, no. 3, pp. 78-88, 2018.

[8] K. Yuliana, Saryani;, and N. Azizah, "Percanangan Rekapitulasi Pengiriman Barang Berbasis Web," J. Sisfotek Glob., vol. 9, no. 1, 2019, doi: http://dx.doi.org/10.38101/sisfotek.v9i1.223.

[9] R. Sabaruddin and W. E. Jayanti, Jago Ngoding Pemrograman Web dengan PHP, no. January. Surabaya: CV. Kanaka Media, 2019.

[10] I. Daqiqil, Framework Codeigniter Sebuah Panduan dan Best Practice. Pekanbaru, 2011.

[11] B. Huda and S. Aripiyanto, "Aplikasi Sistem Informasi Lowongan Pekerjaan Berbasis Android dan Web Monitoring (Penelitian dilakukan di Kab. Karawang) 1Baenil," J. Buana Ilmu, vol. 4, no. 1, pp. 11-24, 2019, doi: https://doi.org/10.35706/sys.v1i2.2076.

[12] R. Mall, Fundamentals of Software Engineering Fourth Edition, 4th ed. Delhi: PHI Learning Private Limited, 2014.

[13] B. Huda and B. Priyatna, "Penggunaan Aplikasi Content Management System (CMS) untuk Pengembangan Bisnis Berbasis E-Commerce," SYSTEMATICS, vol. 1, no. 2, pp. 81-88, 2019, doi: https://doi.org/10.35706/sys.v1i2.2076.

[14] G. Maulani, D. Septiani, and P. N. F. Sahara, "Rancang Bangun Sistem Informasi Inventory Fasilitas Maintenance Pada PT. PLN (Persero) Tangerang," ICIT J., vol. 4, no. 2, pp. 156-167, 2018, doi: 10.33050/icit.v4i2.90.

[15] B. Rumpe, Modeling with UML. Aachen: Springer, 2016. 